\title{
Pronto ${ }^{\circledR}$ ThromboRisk $^{\mathrm{TM}}$-A Novel Primer-Extension ELISA Based Assay for the Detection of Mutations Associated With Increased Risk for Thrombophilia
}

\author{
Noga Carmi, ${ }^{1}$ Dana Cohen, ${ }^{2}$ Eti Zvang, ${ }^{1}$ Elizabeth Naparstek, ${ }^{1}$ and Varda Deutsch ${ }^{1 *}$ \\ ${ }^{1}$ The Hematology Institute, Tel Aviv Sourasky Medical Center, Tel Aviv, Israel \\ ${ }^{2}$ Pronto Diagnostics Ltd., Rehovot, Israel
}

\begin{tabular}{|c|c|}
\hline $\begin{array}{l}\text { The role of inherited thrombophilias in the } \\
\text { pathogenesis of thrombosis, and their rela- } \\
\text { tion to thromboembolic events and preg- } \\
\text { nancy complications, has escalated the } \\
\text { demand for molecular testing. We em- } \\
\text { ployed the new Pronto }{ }^{\mathbb{R}} \text { ThromboRisk }{ }^{\mathrm{TM}} \\
\text { kit (Pronto Diagnostics Ltd., Rehovot, Is- } \\
\text { rael), which is based on a novel primer- } \\
\text { extension ELISA assay, for the simulta- } \\
\text { neous detection of three genetic mutations. } \\
\text { These are Factor V Leiden G1691A } \\
\text { (R506Q), prothrombin G20210A, and methy- } \\
\text { lenetetrahydrofolate reductase (MTHFR) } \\
\text { C677T, which are known to have increased } \\
\text { incidence in patients with thromboembolic } \\
\text { events and pregnancy complications. } \\
\text { We examined } 284 \text { randomly selected } \\
\text { patient samples from the special coagula- }\end{array}$ & $\begin{array}{l}\text { tion hospital laboratory. The results using } \\
\text { the new assay were compared to those } \\
\text { obtained by routinely employed conven- } \\
\text { tional molecular techniques. The Throm- } \\
\text { boRisk }{ }^{\mathrm{TM}} \text { kit provided identical results with } \\
\text { no false-negative results and with a high } \\
\text { specificity of over } 99 \% \text { for all three } \\
\text { mutations. We conclude that the Pronto } \\
\text { ThromboRisk } \\
\text { and reliable testing for the three genetic } \\
\text { mutations. The assay is easy to perform } \\
\text { and provides a useful tool for screening } \\
\text { high risk populations, such as patients } \\
\text { with a personal or family history of venous } \\
\text { thromboembolism, women with preg- } \\
\text { nancy complications, or users of oral } \\
\text { contraceptives. J. Clin. Lab. Anal. } \\
\text { 18:259-264, 2004. @ } 2004 \text { Wiley-Liss, Inc. }\end{array}$ \\
\hline \multicolumn{2}{|c|}{ Key words: thrombophilia risk mutations; detection; Pronto ${ }^{\circledR}$ ThromboRisk $^{\mathrm{TM}}$ kit } \\
\hline
\end{tabular}

\section{INTRODUCTION}

In recent years, there has been a rapidly increasing interest in the role of inherited familial thrombophilias in the pathogenesis of thrombosis and their relation to thromboembolic events and pregnancy complications. Several new thrombophilic mutations have been discovered, and the awareness to their clinical implications as significant risk factors for thrombotic episodes is escalating. Three newly discovered genetic mutations, Factor V Leiden G1691A (R506Q), prothrombin G20210A, and methylenetetrahydrofolate reductase (MTHFR) C677T, are known to have increased incidence in patients with thromboembolic events and pregnancy complications.

The Factor V Leiden mutation originally described by Bertina et al. in 1994 (1), results in a protein that is resistant to inactivation by activated protein C (APC) $(2,3)$. Activated Protein $\mathrm{C}$ limits clot formation by proteolytic inactivation of Factor V. The G1691A mutation, a single point mutation at nucleotide position
1691 that causes a $\mathrm{G} \rightarrow \mathrm{A}$ substitution in the Factor $\mathrm{V}$ gene, renders Factor $\mathrm{V}$ resistant to proteolysis and leads to a prothrombotic state and an increased risk of venous thromboembolism (4). Homozygosity for the G1691A mutation confers a higher risk of thrombosis than heterozygosity $(5,6)$. In homozygous patients, spontaneous thrombosis occurs more frequently at an earlier mean age and at a higher recurrence rate after the first event compared to heterozygous patients. Heterozygosity to the G1691A mutation is present in about $4-10 \%$ of Western populations (7). It is the most commonly inherited risk factor predisposing to venous thrombosis, occurring in $20 \%$ of patients with a first episode of

*Correspondence to: Varda Deutsch, PhD, The Hematology Institute, Tel Aviv Sourasky Medical Center, Weizman St 6, Tel Aviv, 64239 Israel. E-mail: Varda@tasmc.health.gov.il

Received 18 November 2003; Accepted 16 April 2004

DOI $10.1002 /$ jcla. 20034

Published online in Wiley InterScience (www.interscience.wiley.com). 
venous thrombosis and up to $50 \%$ of those with recurrent venous thrombosis $(1,8)$. It also significantly increases the risk of thrombosis in relation to the use of oral contraceptives $(9,10)$. Factor V Leiden also has a well-recognized role in pregnancy complications and multiple miscarriages (11-14).

Prothrombin (Factor II) is the precursor of the serine protease thrombin, a key enzyme in the processes of hemostasis and thrombosis that exhibits procoagulant, anticoagulant, and antifibrinolytic activities. A single point mutation (guanine-to-adenine transition) at position 20210 in the $3^{\prime}$ untranslated region of the prothrombin gene (G20210A) is associated with elevated prothrombin plasma levels and an increased risk of venous and arterial thromboembolism (15-18) and pregnancy complications $(12,13)$. The mutation in its homozygous form is extremely rare $(2,15)$. The mutation in its heterozygous form is present in $1-2 \%$ of the population $(15,19)$; it was found in $6.3 \%$ of consecutive unselected patients with a first episode of deep vein thrombosis and $18 \%$ of selected patients with familial venous thrombosis (15). The risk for venous thromboembolism in patients with the Factor V Leiden mutation and the G20210A prothrombin gene mutation is disproportionately higher than that among patients with only one mutation (20).

MTHFR (5,10-methylenetetrahydrofolate reductase) is the primary methyl donor in the conversion of homocysteine to methionine. A thermolabile form of this enzyme caused by a point mutation at nucleotide 677 is considered a major cause of genetic predisposition to homocysteinaemia, which is known to be a risk factor for cerebrovascular, peripheral vascular, and coronary heart disease. Reduced activity of this enzyme can cause high plasma homocysteine concentrations and increased risk of venous and arterial thrombosis (21-27).

We employed a new assay in screening patients for the three relatively common mutations in randomly selected patients undergoing thrombophilia testing in our coagulation laboratory. The Pronto ${ }^{\circledR}$ ThromboRisk $^{\mathrm{TM}}$ kit (Pronto Diagnostics Ltd., Rehovot, Israel) uses a single nucleotide primer-extension assay technique for the simultaneous identification of predefined polymorphisms for these three mutations.

The results achieved using the new method were confirmed by using conventional PCR restriction enzyme methods for the same patient samples.

\section{MATERIALS AND METHODS}

\section{Patient Samples}

We tested 284 randomly selected blood samples taken from patients undergoing routine thrombophilia screening in the special coagulation laboratory. Venous blood was collected into citrated tubes at room temperature. DNA was purified from whole blood in ethylene diamine tetra acetic acid (EDTA) by salt precipitation.

\section{The Pronto ${ }^{\circledR}$ Procedure}

The Pronto ${ }^{\circledR}$ procedure detects predefined polymorphisms in DNA sequences, using a single nucleotide primer-extension ELISA assay (28-30). Two steps are carried out prior to using the kit: 1) genomic DNA is extracted from whole blood and 2) DNA fragments that encompass the tested mutations are amplified and serve as the template for subsequent steps carried out using the kit.

\section{DNA Amplification}

Pronto ${ }^{\circledR}$ ThromboRisk ${ }^{\mathrm{TM}}$ kit is a postamplification mutation detection assay. The targeted gene fragments Factor V gene- at $220 \mathrm{bp}$, prothrombin gene- at $420 \mathrm{bp}$, and MTHFR gene- at $200 \mathrm{bp}$-were amplified using a multiplex amplification mix provided with the kit.

Two units of Taq DNA polymerase enzyme (Sigma, St. Louis, MO) were added to the reaction mixture that was overlaid with ColoRed ${ }^{\mathrm{TM}}$ Oil (Pronto Diagnostics Ltd., Rehovot, Israel). The amplifications were carried out in a PTC thermal controller (MJ Research Inc., Waltham, MA) following the cycling protocol advised by the Pronto ${ }^{\circledR}$ ThromboRisk ${ }^{\mathrm{TM}}$ kit insert. The amplified products were verified by gel electrophoresis (Fig. 1).

\section{Postamplification treatment}

The amplified DNA product $(15 \mu \mathrm{l})$ was mixed with $60 \mu 1$ of the postamplification buffer reagent in order to inactivate the remaining free nucleotides. The reaction mixtures were covered with oil and incubated for $30 \mathrm{~min}$ at $37^{\circ} \mathrm{C}$, followed by $10 \mathrm{~min}$ at $95^{\circ} \mathrm{C}$. The

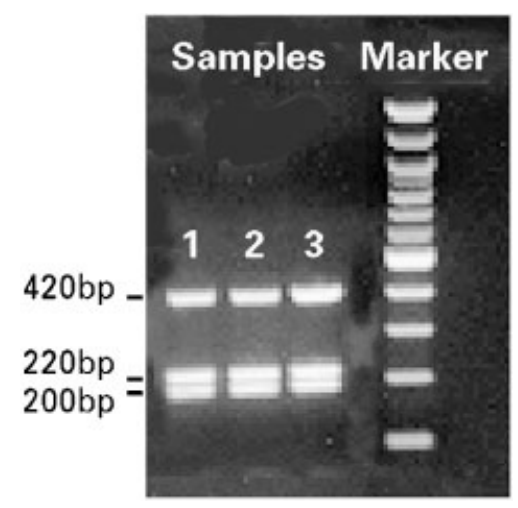

Fig. 1. Verification of the multiplex amplification products. Amplified DNA product $(5 \mu \mathrm{l})$ was separated by gel electrophoresis in $2 \%$ agarose gel and visualized with ethidium bromide. 


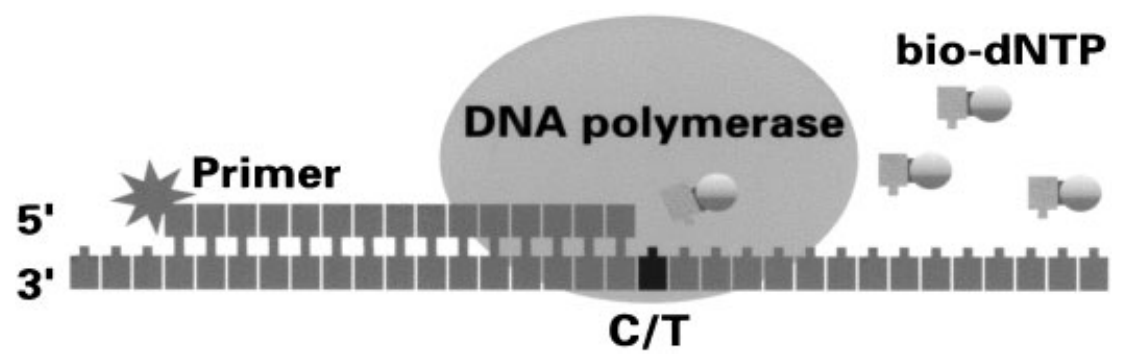

Fig. 2. DNA polymerase extends a $5^{\prime}$ FITC-labeled primer with a single biotinylated nucleotide that complements the nucleotide at the tested site.

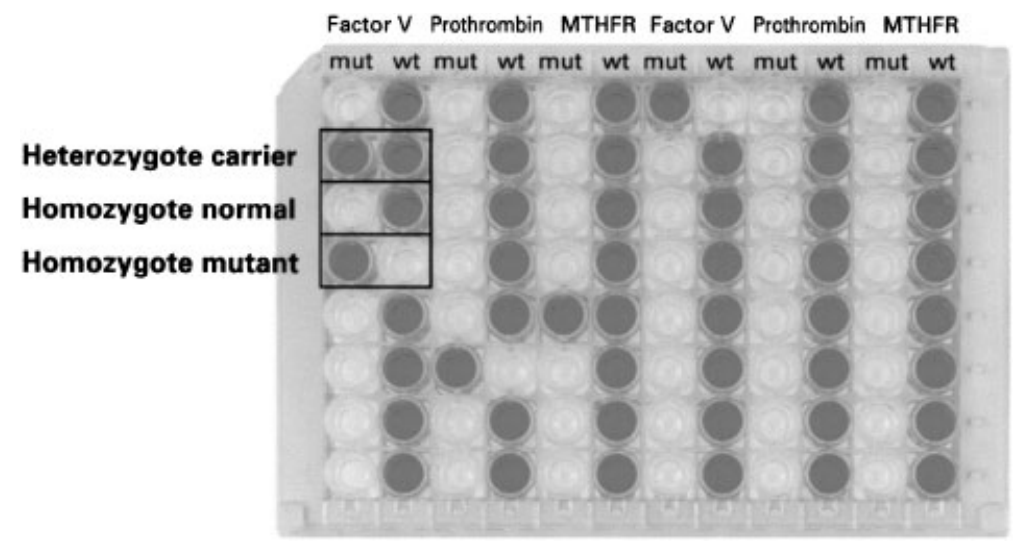

Fig. 3. Visual genotype assignment coloration in the mut well alone indicated the presence of a homozygous for the tested mutation, while coloration in the $w t$ well alone indicated the absence of the tested mutation, or normal genotype. Coloration in both wells indicated that the tested individual is heterozygous for the tested mutation.

primer-extension reaction for each mutation was tested in two wells of the Pronto ${ }^{\circledR}$ ThromboRisk ${ }^{\mathrm{TM}}$ 96microtitter plate, one well for the mutant allele $(m u t)$ and the other for the normal, or wild type $(w t)$. Each well was coated with a $5^{\prime}$ fluorescein isothiocyanate (FITC) labeled primer, complementary to the upstream sequence of the mutation site, and utilized a single biotinylated nucleotide (bio-dNTP) (Fig. 2). The postamplification treated DNA $(8 \mu \mathrm{l})$ was dispensed into the six wells designated to detect the wild type and mutant alleles. The reaction mixture was covered with ColoRed ${ }^{\mathrm{TM}}$ Oil and thermo-cycled according to the kit's protocol.

\section{Detection}

Reaction products were diluted and transferred to a streptavidin-coated 96-well ELISA plate, where the biotin-labeled products were bound (Fig. 3). Following a short incubation period, unbound primers were washed away and a conjugated horseradish peroxidase (HRP) anti-FITC was added. Peroxidase reaction took place in the presence of the HRP substrate. Full color was developed after $30 \mathrm{~min}$ incubation at room temperature.
TABLE 1. O.D readings analyzed according to standard cut-off and mut/wt ratio values

\begin{tabular}{llcc}
\hline & \multicolumn{2}{c}{ O.D. 620nm } & \\
\cline { 2 - 3 } Genotyope & $m u t$ & $w t$ & Ratio mut/wt \\
\hline Normal & $<0.35$ & $>0.5$ & $<0.5$ \\
Heterozygote & $>0.5$ & $>0.5$ & $0.6-1.7$ \\
Homozygote & $>0.5$ & $<0.35$ & $>2.0$ \\
\hline
\end{tabular}

Results can be determined either visually (by the presence of a blue color), or colorimetrically, using an ELISA reader. We used an ELISA reader (THERMOmax microplate reader; Molecular Devices, Sunnyvale, CA). Optical density readings (O.D. 620nm) were analyzed according to standard cut-off and mutant/wild type (mut/wt) ratio values (Table 1 ).

\section{The Restriction Enzyme Method}

Each sample was tested in parallel by a conventional PCR endonuclease method, using Mnl I restriction 
enzyme for Factor V Leiden, HinD III for FII G20210A, and Hinf I for MTHFR. PCR primers used were:

Factor V Leiden gene-

For: CAT ACT ACA GTG ACG TGG AC

Rev: TGT TCT CTT GAA GGA AATG

Prothrombin gene-

For: CAA CCG CTG GTA TCA AAT GG

Rev: ATA GCA CTG GGA GCA TTG AAG C

MTHFR gene-

For: (exon) TGA AGG AGA AGG TGT CTG CGG

GA

Rev: (intron) AGG ACG GTG CGG TGA GAG TG

\section{RESULTS}

\section{Factor V Leiden G1691A}

Using the conventional method, we found 54 patients with the mutant gene and 230 patients with the wild type gene (Table 2). The Pronto ${ }^{\circledR}$ ThromboRisk ${ }^{\mathrm{TM}}$ procedure identified all the 54 mutant samples and 227 normal patients. There were no false-negative results, and only three "undetermined" results were found using the Pronto ${ }^{\mathbb{R}}$ ThromboRisk ${ }^{\mathrm{TM}}$ procedure, owing to technical rejects that necessitated repeating the procedure. Upon repeated testing under corrected technical conditions, a normal phenotype was demonstrated. Thus, the sensitivity and specificity of the Pronto ${ }^{\circledR}$ ThromboRisk $^{\mathrm{TM}}$ procedure for the detection of Factor $\mathrm{V}$ Leiden was $100 \%$ (Table 3). It is important to emphasize that there was complete agreement between the two methods regarding the identification of homozygous and heterozygous patients for the Factor V mutation.

\section{Prothrombin (Factor II) Mutation G20210A}

Using the conventional method (Table 2), 283 patients were tested. This mutation was found in 39 samples, while 244 were found to be normal. The Pronto $^{\circledR}$ ThromboRisk ${ }^{\mathrm{TM}}$ procedure identified the 39 patients with the mutant gene and 240 normal patients.
Two normal samples were classified as "undetermined" (technical rejects that necessitated repeated testing), and two gave false-positive results. Upon repeated testing, all four samples gave normal results. Thus, the sensitivity of the Pronto ${ }^{\circledR}$ ThromboRisk $^{\mathrm{TM}}$ procedure was $100 \%$ with no false-negative results, and the specificity was $99.16 \%$ (Table 3 ).

\section{MTHFR C677T}

Using the conventional method, we found 107 samples with the mutation (homozygous) and 177 heterozygous or wild type (Table 2). With the Pronto ${ }^{\circledR}$ ThromboRisk $^{\mathrm{TM}}$ procedure, we identified 108 patients with the mutant gene and 174 patients without the mutation. There was one false-positive result and two normal samples $(0.7 \%)$ that were classified as "undetermined" due to low signal. Here, as well, there were no false-negative results. The sensitivity of the Pronto ${ }^{\circledR}$ ThromboRisk ${ }^{\mathrm{TM}}$ procedure for the detection of the MTHFR gene mutation was $100 \%$, and the specificity $99.42 \%$ (Table 3 ).

\section{DISCUSSION}

In recent years, there is an increased awareness of the importance of hereditary thrombophilia risks and their relation to thromboembolic events and pregnancy complications. This enhanced the demand for molecular testing for the genetic mutations related to thrombophilia. Factor V Leiden is the most commonly inherited thrombophilic risk factor, with the mutation present in

TABLE 3. Sensitivity and specificity of the Pronto ${ }^{\circledR}$ method for each mutation

\begin{tabular}{lcc}
\hline \multicolumn{1}{c}{ Mutation } & Sensitivity $(\%)$ & Specificity $(\%)$ \\
\hline Factor V Leiden & 100 & 100 \\
FII G20210A & 100 & 99.16 \\
MTHFR & 100 & 99.42 \\
\hline
\end{tabular}

TABLE 2. Test results comparing the two methods

\begin{tabular}{|c|c|c|c|c|c|}
\hline \multirow[b]{2}{*}{ Mutation } & \multicolumn{2}{|c|}{ Conventional method } & \multicolumn{3}{|c|}{ The Pronto ${ }^{\circledR}$ Method } \\
\hline & Normal & Mutation & Normal & Mutation & Undetermined $^{\mathrm{a}}$ \\
\hline FV Leiden $(\mathrm{n}=284)$ & 230 & 54 & 227 & 54 & 3 \\
\hline FII G20210A $(n=283)$ & 244 & 39 & 240 & 41 & 2 \\
\hline MTHFR $(n=284)$ & 177 & 107 & 174 & 108 & 2 \\
\hline
\end{tabular}

${ }^{a}$ Undetermined results were obtained due to poor quality of the DNA or the amplified products introduced into the assays as verified using gel electrophoresis. 
about $4-10 \%$ of Western populations (7). The prothrombin gene mutation (G20210A), though not as common, is another important prothrombotic factor. Hyperhomocysteinemia, caused by decreased synthesis of MTHFR due to a point mutation (C677T) in the gene encoding MTHFR production, is related to an increased risk of venous and arterial thrombosis. Identifying these three mutations has already been incorporated into routine thrombophilia screening. There are several methods for the detection of these mutations. The most commonly used method is complicated requiring PCR techniques, gel electrophoresis to verify the PCR reaction, endonuclease digestion of the product, a second gel electrophoresis, and identification of the resulting bands having the appropriate molecular weight. This method is time consuming and costly. In order to fulfill the increased demand for facile molecular screening of these disorders, better methods are essential.

We have described a newly developed ELISA-based primer-extension method for the detection of three common thrombophilic mutations. The Pronto ${ }^{\circledR}$ ThromboRisk $^{\mathrm{TM}}$ procedure uses a single nucleotide primer-extension assay for the simultaneous detection of the three mutations. We tested 284 DNA samples of patients undergoing thrombophilia screening in our laboratory. By confirming the results achieved with the new assay using a conventional enzyme restriction method, the sensitivity of the Pronto ${ }^{\circledR}$ ThromboRisk $^{\mathrm{TM}}$ procedure for the detection of all three mutations was found to be $100 \%$, with no false-negative results. The specificity was very high as well, ranging over $99 \%$. It is important to emphasize that regardless of the method used, detection of any mutation requires reconfirmation before reporting to the patient or the physician. Concerning Factor V Leiden, we found a complete agreement between the two methods regarding the identification of homozygous and heterozygous states; this is important in view of the higher clinical risk for homozygous patients $(5,6)$.

Thus, the Pronto ${ }^{\circledR}$ ThromboRisk ${ }^{\mathrm{TM}}$ procedure is a very sensitive and accurate method for the detection of major thrombophilic states. One must not forget that the success of all post-PCR methodologies depends on the quality of the DNA and the amplified product introduced. Pronto ${ }^{\circledR}$ is a post-PCR detection kit, and, therefore, we recommend complying with the manufacturer's instructions. The reliability and efficiency of this method have been reported in several publications in recent years for detecting point mutations in different medical fields. For example, the apolipoprotein E polymorphism, the APC gene related to increased risk for colorectal cancer, and mutations related to congenital diseases common in the Jewish population are routinely in use in clinical laboratories around the world as part of prenatal screening (29-32). The significance of developing easier laboratory methods for detecting thrombophilia risk factors is obvious.

\section{REFERENCES}

1. Bertina RM, Koeleman BPC, Koster T, et al. Mutation in blood coagulation factor $\mathrm{V}$ associated with resistance to activated protein C. Nature 1994;369:64-67.

2. Koster T, Rosendaal FR, de Ronde H, Briet E, Vandenbroucke JP, Bertina RM. Venous thrombosis due to poor anticoagulant response to activated protein $\mathrm{C}$ : Leiden thrombophilia study. Lancet 1993;342:1503-1506.

3. Svensson PJ, Dählback B. Resistance to activated protein C as a basis for venous thrombosis. N Engl J Med 1994;330:517-522.

4. Dahlback B. Inherited resistance to activated protein $\mathrm{C}$, a major cause of venous thrombosis, is due to a mutation in the factor $\mathrm{V}$ gene. Haemostasis 1994;24:139-151.

5. Rosendaal FR, Koster T, Vandenbroucke JP, Reitsma PH. High risk of thrombosis in patients homozygous for factor $\mathrm{V}$ Leiden (APC-resistance). Blood 1995;85:1504-1508.

6. Procare Group. Comparison of thrombotic risk between 85 homozygotes and 481 heterozygotes carriers of the factor $\mathrm{V}$ Leiden mutation: retrospective analysis from the Procare Study. Blood Coagul Fibrinolysis 2000;11:511-518.

7. Rees DC, Cox M, Clegg JB. World distribution of factor V Leiden. Lancet 1995;346:1133-1134.

8. Ridker PM, Miletich JP, Stampfer MJ, Goldhaber SZ, Lindpaintner K, Hennekens CH. Factor V Leiden and risk of recurrent idiopathic venous thrombosis. Circulation 1995;92: 2800-2802.

9. Vandenbroucke JP, Koster T, Briet E, Reitsma PH, Bertina RM, Rosendaal FR. Increased risk of venous thrombosis in oral contraceptive users who are carriers of factor V Leiden mutation. Lancet 1994;344:1453-1457.

10. Bloemenkamp KW, Rosendaal FR, Helmerhorst FM, Buller HR, Vandenbruocke JP. Enhancement by factor V Leiden mutation of risk of deep-vein-thrombosis associated with oral contraceptives containing a third-generation progestagen. Lancet 1995;346: 1593-1596.

11. Preston FE, Rosendaal FR, Walker ID, et al. Increased fetal loss in women with heritable thrombophilia. Lancet 1996;348: 913-916.

12. Kupferminc MJ, Eldor A, Steinman N, et al. Increased frequency of genetic thrombophilia in women with complications of pregnancy. N Engl J Med 1999;340:9-14.

13. Martinelli I, Taioli E, Cetin I, et al. Mutations in coagulation factors in women with unexplained late fetal loss. N Engl J Med 2000;343:1015-1018.

14. Many A, Elad R, Eldor A, Lessing JB, Kupferminc MJ. Third trimester unexplained intra uterine fetal death and thrombophilia. Society of Maternal Fetal Medicine, 2001, Reno, Nevada. Am J Obstet Gynecol 2001;184:16 (abstract).

15. Poort SR, Rosendaal FR, Reitsma PH, Bertina RM. A common genetic variation in the $3^{\prime}$-untranslated region of the prothrombin gene is associated with elevated plasma prothrombin levels and an increase in venous thrombosis. Blood 1996;88:3698-3703.

16. Rosendaal FR, Siscovick DS, Schwartz SM, Psaty BM, Raghunathan TE, Vos HL. A common prothrombin variant (20210 G to A) increases the risk of myocardial infarction in young women. Blood 1997;90:1747-1750.

17. Doggen CJM, Cats VM, Bertina RM, Rosendaal FR. Interaction of coagulation defects and cardiovascular risk factors: increased 
risk of myocardial infarction associated with Factor V Leiden or Prothrombin 20210A. Circulation 1998;97:1037-1041.

18. Martinelli I, Sacchi E, Landi G, Taioli E, Duca F, Mannucci PM. High risk of cerebral-vein thrombosis in carriers of a prothrombingene mutation and in users of oral contraceptives. N Engl J Med 1998;338:1793-1797.

19. Cumming AM, Keeney S, Salden A, Bhavnani M, Shwe KH, Hay CR. The prothrombin gene G20210A variant: prevalence in a U.K. anticoagulant clinic population. Br J Haematol 1997;98:353-355.

20. Gerhardt A, Scharf RE, Beckmann MW, et al. Prothrombin and Factor $\mathrm{V}$ mutations in women with a history of thrombosis during pregnancy and the puerperium. N Engl J Med 2000;342:374-380.

21. Frosst P, Bloom HJ, Milos R, et al. A candidate genetic risk factor for vascular disease: a common mutation in methylenetetrahydrofolate reductase. Nat Genet 1995;10:111-113.

22. Kluijtmans LA, van den Heuvel LP, Boers GH, et al. Molecular genetic analysis in mild hyperhomocysteinemia: a common mutation in the methylenetetrahydrofolate reductase gene is a genetic risk factor for cardiovascular disease. Am J Hum Genet 1996;58:35-41.

23. Alfthan G, Aro A, Gey KF. Plasma homocysteine and cardiovascular disease mortality. Lancet 1997;349:397.

24. Nygard O. Plasma homocysteine and mortality in patients with coronary artery disease. N Engl J Med 1997;337:230-236.

25. Eichinger S, Stumpflen A, Hirschl M, et al. Hyperhomocysteinemia is a risk factor of recurrent venous thromboembolism. Thromb Haemost 1998;80:566-569.
26. Kluijtmans LA, den Heijer M, Reitsma PH, et al. Thermolabile methylenetetrahydrofolate reductase and factor $\mathrm{V}$ Leiden in the risk of deep-vein thrombosis. Thromb Haemost 1998;79: 254-258.

27. Margaglione $\mathbf{M}$, D'Andrea $\mathrm{G}$, d'Addedda $\mathrm{M}$, et al. The methylenetetrahydrofolate reductase TT677 genotype is associated with venous thrombosis independently of the coexistence of the FV Leiden and the prothrombin A20210 mutation. Thromb Haemost 1998;79:907-911.

28. Wilde JT, O'Sullivan JJ, Roper JL, Aerts P, Horowitz M, Navot N. A novel ELISA-based primer extension assay for the detection of the factor $\mathrm{V}$ Leiden mutation. $\mathrm{Br} \mathbf{J}$ Haematol 1999; 106:427-430

29. McLeod DA, Arnott B, Gaudreault N, et al. A comparison of two methods for routine, accurate determination of apolipoprotein $\mathrm{E}$ genotypes. Alzheimer's Reports 1998;1:211-215.

30. Rozen P, Shomrat R, Strul H, et al. Prevalence of the I1307K APC gene in Israeli Jews of differing ethnic origin and risk of colorectal cancer. Gastroenterology 1999;116:54-57.

31. Horowitz M, Pasmanic-Chor M, Borochowitz Z, et al. Prevalence of glucocerebrosidase mutations in the Israeli Ashkenazi Jewish population. Hum Mutat 1998;12:240-244.

32. Peleg L, Pesso R, Goldman B, et al. Bloom syndrome and Fanconi's anemia: rate and ethnic origin of mutation carriers in Israel. Isr Med Assoc J 2002;4:95-97. 